\title{
Occurrence and elimination of cyanobacterial toxins in two Australian drinking water treatment plants
}

\author{
Stefan J. Hoeger ${ }^{\mathrm{a}, *}$, Glen Shaw ${ }^{\mathrm{b}}$, Bettina C. Hitzfeld ${ }^{\mathrm{c}}$, Daniel R. Dietrich ${ }^{\mathrm{a}}$ \\ ${ }^{a}$ Environmental Toxicology, University of Konstanz, P.O. Box X918, 78457 Konstanz, Germany \\ ${ }^{\mathrm{b}}$ National Research Centre for Environmental Toxicology (En Tox), 39 Kessels Road, Coopers Plains, Brisbane 4108, Australia \\ ${ }^{\mathrm{c}}$ Swiss Agency for the Environment, 3003 Bern, Switzerland
}

\begin{abstract}
In Australian freshwaters, Anabaena circinalis, Microcystis spp. and Cylindrospermopsis raciborskii are the dominant toxic cyanobacteria. Many of these surface waters are used as drinking water resources. Therefore, the National Health and Medical Research Council of Australia set a guideline for MC-LR toxicity equivalents of $1.3 \mu \mathrm{g} / \mathrm{l}$ drinking water. However, due to lack of adequate data, no guideline values for paralytic shellfish poisons (PSPs) (e.g. saxitoxins) or cylindrospermopsin (CYN) have been set. In this spot check, the concentration of microcystins (MCs), PSPs and CYN were determined by ADDA-ELISA, cPPA, HPLC-DAD and/or HPLC-MS/MS, respectively, in two water treatment plants in Queensland/Australia and compared to phytoplankton data collected by Queensland Health, Brisbane. Depending on the predominant cyanobacterial species in a bloom, concentrations of up to 8.0, 17.0 and $1.3 \mu \mathrm{g} / \mathrm{l}$ were found for MCs, PSPs and CYN, respectively. However, only traces $(<1.0 \mu \mathrm{g} / \mathrm{l})$ of these toxins were detected in final water (final product of the drinking water treatment plant) and tap water (household sample). Despite the low concentrations of toxins detected in drinking water, a further reduction of cyanobacterial toxins is recommended to guarantee public safety.
\end{abstract}

Keywords: Microcystin; Saxitoxins; Cylindrospermopsin; Anabaena circinalis; Microcystis aeruginosa; Cylindrospermopsis raciborskii

\section{Introduction}

The presence of toxic cyanobacterial blooms in water bodies used either as drinking water or for recreational

Abbreviations: Adda, (2S, 3S, 8S, 9S)-3-amino-9-methoxy2,6,8-trimethyl-10-phenyldeca-4,6-dienoic acid; ASF, after sand filtration; cPPA, colorimetric protein phosphatase assay; CYN, cylindrospermopsin; DAD, diode array detector; DW, dry weight; ELISA, enzyme linked immunosorbent assay; GAC, granular activated carbon; HPLC, high performance liquid chromatography; LD, lethal dose; LPS, lipopolysaccharide; MC, microcystin; NOD, nodularin; PAC, powdered activated carbon; PSP, paralytic shellfish poison; QHSS, Queens Health Scientific Services; QSL, Queensland; UV, ultraviolet; WTP, water treatment plant; WHO, World Health Organisation.

* Corresponding author. Tel.: +49-7531-884661; fax: +497531-883170.

E-mail addresses: stefan.hoeger@uni-konstanz.de(S.J.Hoeger); daniel.dietrich@uni-konstanz.de (D.R. Dietrich). purposes may present serious health risks for the human population. Safe drinking water is one of the most critical factors to guarantee long-term population health. In Australia about $70 \%$ of drinking water comes from surface waters. Due to climatic conditions in many parts of this continent as well as due to the nutrient load from agriculture, the phytoplankton of reservoirs, lakes and rivers is often predominated by cyanobacteria (blue-green algae). For example, the $1000 \mathrm{~km}$ bloom of the Darling-Barwon river in 1991 caused a loss of one million people-days of drinking water (Herath, 1995). Water conservation and management is therefore a critical national issue in Australia. Water treatment plants not only have to reduce cyanobacterial cells, odour and colour during the water treatment process, they also have to eliminate the toxins produced by cyanobacteria. Cyanobacteria synthesize a variety of toxins, usually defined by their chemical structure, that fall into three groups: cyclic peptides (e.g. the hepatotoxic microcystins (MCs) cylindrospermopsin (CYN) and nodularins 
(NODs)), alkaloids (e.g. the neurotoxic paralytic shellfish poisons (PSPs) and anatoxins), and lipopolysaccharides (LPS). The cyclic peptide toxins are the most widespread freshwater cyanobacterial toxins and are therefore very important regarding treatment of drinking water. Acute intoxications with MCs (heptamer) or NODs (pentamer) result in fulminant liver damage (Runnegar et al., 1988). MCs and NODs are suspected and proven tumour promoters in humans and rodents (Fujiki and Suganuma, 1999), respectively. Concerns over these health risks have prompted the World Health Organization (WHO) to adopt a provisional guideline value for MC-LR ( $\mathrm{L}$ for leucine and $\mathrm{R}$ for arginine) of $1.0 \mu \mathrm{g} / \mathrm{l}$ drinking water (WHO, 1998). The National Health and Medical Research Council of Australia have set the guideline slightly higher to $1.3 \mu \mathrm{g} / \mathrm{l}$ (NHMRZ/ARMCANZ, 2001) but based on all MC-congeners as MC-LR equivalents. The basis for these guideline values is the study from Fawell et al. (1994). Additionally, Fitzgerald et al. (1999) proposed the publication of a health alert if the concentration of $10 \mu \mathrm{g} \mathrm{MCs} / 1$ drinking water is reached for even a brief period. Due to the lack of reliable data, no guideline value is set yet for concentrations of NODs, CYNs or PSPs in drinking water. Acute intoxication of mice with extract of Cylindrospermopsis raciborskii causes massive hepatocyte necrosis. Injuries in kidney, lungs and intestine have also been seen (Hawkins et al., 1985). Genotoxic activity is caused by the ability of CYN to induce strand breaks at the DNA level and loss of whole chromosomes (Humpage et al., 2000). Beside the capacity of CYN to suppress glutathione and protein synthesis, probably by inhibiting ribosomal translation (Froscio et al., 2001), other mechanisms of actions have been assumed as an explanation for the severe liver injuries followed by CYN intoxication, although no protein phosphatase inhibition could be found (Runnegar et al., 1995; Chong et al., 2002). PSPs are potent blockers of voltage-dependent sodium-channels and therefore restrict transmission between neurons. In contrast to the only PSPproducing Australian strains, European and American strains of Anabaena circinalis appear to exclusively synthesize anatoxins (Beltran and Neilan, 2000). In general, the genus Anabaena can produce MCs, PSPs and anatoxin-a with toxin contents of $2 \mathrm{mg} / \mathrm{g}$ dry weight (DW) for MCs
(Rapala and Sivonen, 1998), $4.4 \mathrm{mg} / \mathrm{g}$ DW for PSPs (Velzeboer et al., 2000) and a remarkable $28 \mathrm{mg} / \mathrm{g}$ DW for anatoxin-a (Rapala and Sivonen, 1998). Australia has a documented history of mortalities of livestock (Francis, 1878; Newcombe et al., 2001) and human health impacts (Byth, 1980; Falconer et al., 1983). In order to minimize the risk of cyanotoxic contamination of drinking water, the development of methods to effectively reduce toxin concentrations to below acceptable levels in drinking water has thus become an important focus of current research efforts. The two water treatment plants investigated in this study use a similar treatment process to purify the raw water: flocculation with aluminium sulphate, optional addition of powdered activated carbon (PAC), sedimentation, sand filtration and chlorination before storage. The efficiency of these methods to remove cyanobacterial cells and toxins are controversially discussed in the literature and appear strongly dependent on the following factors (Vlaski et al., 1996; Hitzfeld et al., 2000; Hoeger et al., 2002): cyanobacterial species and density, additional organic load, concentration and type of flocculent and activated carbon, $\mathrm{pH}$ during flocculation and chlorination and maintenance of the treatment system especially of the filter bed (backwashing, etc.).

For the investigation presented here, two water treatment plants were selected that obtain their raw water from surface waters regularly contaminated with toxic cyanobacteria. MCs as well as CYN and different PSPs were detected in raw water of these water treatment plants. Spot checks of efficiency of the water treatment process were compared to literature data and to the phytoplankton situation in these two water reservoirs during 2000/2001.

\section{Materials and methods}

\subsection{Characteristics of the water treatment plants chosen}

The two investigated water treatment plants are located in Queensland/Australia and take their raw water from water reservoirs (Table 1).

Table 1

Treatment system, predominant cyanobacteria and analysed toxins in two water treatment plants in Queensland/Australia

\begin{tabular}{llll}
\hline Location & Water treatment steps & Predominant cyanobacteria & Supplied population \\
\hline $\begin{array}{l}\text { WTP 1 (southeast } \\
\text { QSL/AUS) }\end{array}$ & $\begin{array}{l}\text { Flocculation/sedimentation, } \\
\text { optional PAC, sand filtration, } \\
\text { chlorination }\end{array}$ & M. aeruginosa, A. circinalis & $8000-10,000$ \\
WTP 2 (near & $\begin{array}{l}\text { Flocculation/sedimentation, } \\
\text { optional PAC, sand filtration, } \\
\text { chlorination before storage }\end{array}$ & C. raciborskii & One of the water suppliers for \\
Brisbane, AUS) & & Brisbane (1.5 million people)
\end{tabular}




\subsection{Analysis of cyanobacterial cells at WTP 1}

Water samples were taken from the raw water intake in the dam. They were fixed with lugol's iodine $7 \mathrm{ml} / \mathrm{l}$ of sample. If necessary the sample was concentrated 10 times by sedimentation in a measuring cylinder. This concentrated sample was then mixed by inverting 20 times and $1 \mathrm{ml}$ transferred to a Sedgewick-Rafter counting cell. A minimum of 23 units (trichomes/colonies) of each alga was counted, and a minimum three squares in the chamber. Cells per colony were counted (or estimated for Microcystis aeruginosa) for each colony.

\subsection{Sample preparation}

An overview of the different sample preparations and detection methods used is shown in Table 2. Samples for the spot check investigation were taken at each stage from raw water to final water. The aqueous samples were stored below $10^{\circ} \mathrm{C}$ for a maximum of $48 \mathrm{~h}$ until they are filtered through Millex-GN (Millipore)-filter to separate cell-bound from free toxin. The filter and filtered water were stored at $-20{ }^{\circ} \mathrm{C}$ until toxin extraction and concentration.

\subsubsection{MCs + PSPs at WTP 1 (sample preparation No. 1)}

The cell-bound toxin was extracted by tearing the filter into small pieces, addition of $1.5 \mathrm{ml}$ of $75 \%$ methanol $(\mathrm{MeOH})$ in a $2.0 \mathrm{ml}$ reaction vessel, sonication for $20 \mathrm{~min}$ (cooled water bath) and shaking for $30 \mathrm{~min}$. The methanol/sonication/shaking steps were repeated twice, the supernatants were sampled, combined, dried under nitrogen and redissolved with $10 \mathrm{ml} \mathrm{H}_{2} \mathrm{O}$. For clean-up, $\mathrm{C}_{18}$ solid phase extraction columns (ICT Isolute $\mathrm{C}_{18} \mathrm{EC}, 1 \mathrm{~g} / 6 \mathrm{ml}$ ) were conditioned with $6 \mathrm{ml} \mathrm{MeOH}$, washed with $6 \mathrm{ml} \mathrm{H}_{2} \mathrm{O}$, loaded with sample, washed with $6 \mathrm{ml} \mathrm{H}_{2} \mathrm{O}$ and the toxins were eluted with $12 \mathrm{ml} \mathrm{100 \%} \mathrm{MeOH}$. After drying, pellets were finally dissolved in $2 \mathrm{ml} 50 \% \mathrm{MeOH}$. The toxins in the filtered water $(500 \mathrm{ml})$ were also concentrated by $\mathrm{C}_{18} \mathrm{SPE}$. Cyanobacterial bloom material was freeze dried and stored at $-20{ }^{\circ} \mathrm{C}$. For analysis, $100 \mathrm{mg}$ DW of each sample was extracted with $10 \mathrm{ml} 75 \% \mathrm{MeOH}$, sonicated and shaken. This procedure was repeated twice and the supernatants collected.

\subsection{2. $C Y N+$ MCs at WTP 2 (sample preparation No. 2)}

Free CYN (for HPLC-MS/MS) and MCs (for ELISA, PPA, HPLC-DAD) were isolated via $\mathrm{C}_{18}$ carbograph SPE columns SC-103 by washing the column with $10 \mathrm{ml} \mathrm{H}_{2} \mathrm{O}$ followed by $100 \mathrm{ml}$ of the sample (CYN), $6 \mathrm{ml}$ of $10 \%$ $\mathrm{MeOH}$ and $6 \mathrm{ml}$ of $100 \% \mathrm{MeOH}$ (MCs). Due to the low detection limit, the CYN fraction could be directly analysed by HPLC-MS/MS, whereas the $10 \% \mathrm{MeOH}$ fraction was freeze dried and the $100 \% \mathrm{MeOH}$ fraction dried under nitrogen. Both samples were resolved in $1 \mathrm{ml} \mathrm{H}_{2} \mathrm{O}$. The filters were extracted twice with $1.5 \mathrm{ml} 100 \% \mathrm{MeOH}$ and once with $1.5 \mathrm{ml} 75 \% \mathrm{MeOH}$. Sonication and shaking steps followed by centrifugation were included. The supernatants were combined, dried under nitrogen and redissolved in $1.8 \mathrm{ml} \mathrm{H}_{2} \mathrm{O}$.

\subsubsection{Sample preparation for the weekly samples at} Queensland Health Scientific Services (sample preparation No. 3)

In contrast to the preparation presented above, weekly samples from WTP 1 were sonicated to disrupt any cells and subsequently filtered. MCs and PSPs were analysed by HPLC-DAD or HPLC-FD (fluorescence detector), respectively. For MC detection via HPLC $25 \mathrm{ml}$ of the sonicated and filtered $(0.45 \mu \mathrm{m})$, solution were pumped through a $\mathrm{C}_{18}$ cartridge (Alltima $\mathrm{C}_{18} 7.5 \times 4.6 \mathrm{~mm}^{2}$, guard column) to concentrate the MCs. The cartridge was then switched into the analytical HPLC system.

\subsection{Determination and quantification of the toxins}

\subsubsection{Microcystins}

The colorimetric protein phosphatase assay (cPPA) was performed as described by Heresztyn and Nicholson (2001)

Table 2

Detail of the sample preparation and analytical methods used during the investigations (explanations for numbers, see Section 2)

\begin{tabular}{|c|c|c|c|c|c|}
\hline & & \multicolumn{2}{|l|}{ WTP 1} & \multicolumn{2}{|l|}{ WTP 2} \\
\hline & & $\mathrm{MCs}$ & PSPs & $\mathrm{MCs}$ & CYN \\
\hline \multirow{4}{*}{ Spot check } & $\begin{array}{l}\text { Sample preparation } \\
\text { protocol }\end{array}$ & No. 1 & No. 1 & No. 2 & No. 2 \\
\hline & Analysed by & $\begin{array}{l}\text { HPLC-DAD, cPPA, } \\
\text { Adda-ELISA }\end{array}$ & HPLC-FD & HPLC-DAD, cPPA, Adda-ELISA & HPLC-MS/MS \\
\hline & Days of sampling & \multicolumn{2}{|c|}{$2(01 / 08 / 2001,22 / 08 / 2001)$} & \multirow[t]{2}{*}{$1(21 / 09 / 2001)$} & \\
\hline & $\begin{array}{l}\text { Sample preparation } \\
\text { protocol }\end{array}$ & No. 3 & No. 3 & & \\
\hline \multirow{2}{*}{$\begin{array}{l}\text { Weekly } \\
\text { monitoring }\end{array}$} & Analysed by & HPLC-DAD & HPLC-FD & \multirow[t]{2}{*}{ No data available } & \\
\hline & Days of sampling & 140 & & & \\
\hline
\end{tabular}


using the protein phosphatase 1 (PP1) instead of PP2a with MC-LR (Alexis, Switzerland) as a standard. The PPAinhibiting capacity of the samples was compared to a MC-LR standard-curve and expressed as MC-LR equivalents. The detection range (20-80\% inhibition of PP1) of the colorimetric PPA used is $0.9-3.2 \mu \mathrm{g}$ MC-LR/l with a derived $\mathrm{IC}_{50}$ of $1.7 \mu \mathrm{g}$ MC-LR/l. As a structural biological test system, an ADDA-ELISA established by Fischer et al. (2001) was used. The limits of quantitation and detection of the ELISA were 0.2 and $0.05 \mu \mathrm{g} / \mathrm{l}$, respectively. For HPLC analysis, samples were analysed, based on the method of Lawton et al. (1994). MCs were identified by their characteristic UV spectra using a diode array detector. Quantitation was performed by comparing the areas of the MC peaks identified in the sample to the area of a standard MC-LR of known concentration. Including preconcentration, a detection limit of $0.2 \mu \mathrm{g} / \mathrm{l}$ for individual MCs was achievable.

\subsubsection{Paralytic shellfish poisons}

Samples were analysed by HPLC according to the method described by Lawrence et al. (1995). PSPs were oxidised using hydrogen peroxide and analysed using a Shimadzu LC-10ADVp HPLC system with a Shimadzu RF-10AXL fluorescence detector set at an extinction wavelength of $330 \mathrm{~nm}$ and an emission wavelength of $390 \mathrm{~nm}$. PSPs were identified and quantified by comparison to standards obtained from National Research Council, Canada. Detection limits vary for individual PSPs, however, a detection limit for PSPs of $0.5 \mu \mathrm{g} / \mathrm{l}$ is achievable.

\subsubsection{Cylindrospermopsin}

CYN was determined by HPLC-MS/MS using a PE/Sciex API 300 mass spectrometer equipped with a turbo-ionspray interface, coupled to a Perkin Elmer series 200 HPLC system (Eaglesham et al., 1999). Quantification of CYN was achieved using the 416.2/194.1 transition with other transitions monitored as confirmation ions. Using a $150 \mu \mathrm{l}$ injection volume the limit of detection using this method is typically less than $0.2 \mu \mathrm{g} / \mathrm{l}$ and response was linear up to at least $1000 \mu \mathrm{g} / \mathrm{l}$.

\section{Results}

\subsection{Phytoplankton and toxin concentrations at WTP 1 monitored over a three-years period}

At WTP 1, extremely high cyanobacterial cell numbers occur in raw water almost continually, M. aeruginosa and A. circinalis being the predominant species (Table 1). A pattern of predominance of these cyanobacterial species in different seasons over the 3 years period is clearly recognizable (partly shown in Fig. 1a-c). Every year in February and March M. aeruginosa and A. circinalis disappeared from raw water and Planktothrix sp. occurred for a short period (Fig. 1b). In 2000 and 2001 M. aeruginosa blooms developed after the February/March period. Between July and September 1999 and 2001, A. circinalis was able to form blooms with high concentrations of PSPs, whereas no bloom occurred during the colder period 1999. In contrast, the year 2000 was predominated by M. aeruginosa without shift to Anabaena (partly shown in Fig. 1b). M. aeruginosa and Australian strains of A. circinalis are known producers of MCs and PSPs, respectively. However, MC concentrations correlated poorly with the cell counts of $M$. aeruginosa $\left(R^{2}=0.19\right)$, even without data from $05 / 2000$ to $03 / 2001$, when no MC could be detected, although a $M$. aeruginosa strain had dominated the phytoplankton with densities of up to $2.2 \times 10^{6}$ cells $/ \mathrm{ml}$ over this period (data not shown). MC concentrations were highest at the beginning and the end of a $M$. aeruginosa dominated period with up to $8.0 \mu \mathrm{g} / \mathrm{l}$, determined by HPLC-DAD. At two time periods $(22 / 02-$ 08/05/2000 and 10/4-14/08/2001) MCs could be found in raw water over months (Fig. $1 \mathrm{~b}$ and c). A. circinalis occurred in densities up to $3.25 \times 10^{5}$ cells $/ \mathrm{ml}$ (Table 3, Fig. 1c) with $R^{2}=0.51$ for the PSP concentrations plotted versus $A$. circinalis densities over the 3 years period. The concentration of PSPs correlated to A. circinalis abundance with an estimated toxin concentration of $0.12 \mathrm{pg}$ PSP/cell. In 23.3 and $22.7 \%$ of the weekly raw water samples MCs and PSPs could be detected, respectively. At least, one of theses two toxin families could be determined in $36 \%$ of the samples. In 2 of 52 final water samples traces of PSPs (below $0.5 \mu \mathrm{g} / \mathrm{l}$ ) were found, but no MCs were detectable. No toxin reached the tap water in detectable concentrations.

\subsection{Elimination of cyanobacterial cells during a 46-week period at WTP 1}

During the investigated period (11/2000-09/2001) cyanobacterial densities reached $1.26 \times 10^{6}$ cells $/ \mathrm{ml}$ in raw water (M. aeruginosa). On average, the water treatment plant had to eliminate $3.7 \times 10^{5}$ cyanobacterial cells $/ \mathrm{ml}$ from the raw water (Table 3 ). In final and tap water, the cell densities were reduced by $>99 \%$ (Fig. 2). Table 3 shows in detail the cell counts for total cyanobacteria and for the predominant cyanobacterial species in raw water at this water treatment plant. On average, only $0.04 \%$ of the A. circinalis cells found in raw water were still present in final and tap water. In contrast, 0.76 and $0.55 \%$ of $M$. aeruginosa cells occurred in final and tap water, respectively. Of note are large standard deviations in these cases as indication for a high variation in elimination of Microcystis cells. Not included in Fig. 2 are data from 20/02/2001 to 27/ 03/2001 with low cell counts in raw water, but still high cell numbers in final water tanks (from the preceding period with higher cell densities). 

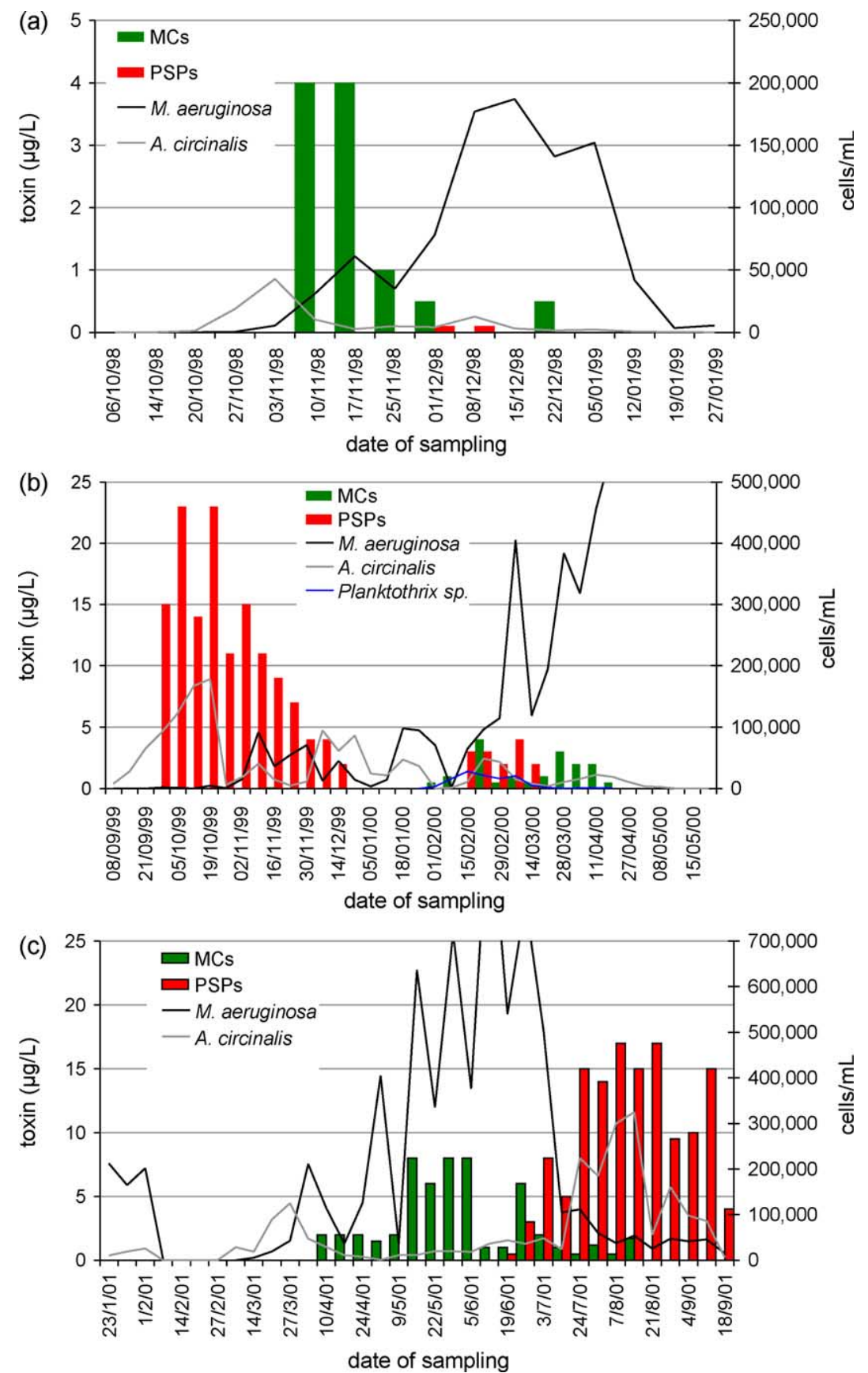

Fig. 1. $(\mathrm{a}-\mathrm{c})$ Cyanobacterial cell concentrations and toxin concentrations during periods of competition between different cyanobacterial species in Dam at WTP 1.

\subsection{Reduction of cyanobacterial cell numbers}

During a period of high cell densities of $M$. aeruginosa and $A$. circinalis between $05 / 06 / 2001$ and $01 / 08 / 2001$ the efficiencies of flocculation $(n=15)$ and of filtration $(n=5)$ were investigated in detail. Cells were reduced by $99 \%$ through flocculation/sedimentation without differences between the cyanobacterial species (data not shown). However, due to high cell counts in raw water, up to 12,400 cells $/ \mathrm{ml}$ were still present after this first treatment step. In contrast, the efficiency of sand filtration for the removal of A. circinalis (99\%) was higher than for M. aeruginosa (84.8\%). In summary, these investigations demonstrated an efficiency of $>99.9 \%$ for flocculation 
Table 3

WTP 1: cyanobacterial cell concentration in raw $(n=182)$, final $(n=55)$ and tap water $(n=5)$

\begin{tabular}{|c|c|c|c|c|}
\hline & Total & M. aeruginosa & A. circinalis & $\begin{array}{l}\text { Other } \\
\text { cyanobacteria }\end{array}$ \\
\hline \multicolumn{5}{|c|}{ Raw water (cells $/ \mathrm{ml})$} \\
\hline Average & 373,425 & 326,234 & 40,227 & 6963 \\
\hline$\%$ & 100 & 87.4 & 10.8 & 1.9 \\
\hline Max & $1,259,100$ & $1,220,000$ & 325,000 & 7250 \\
\hline Min & 500 & 0 & 0 & 0 \\
\hline \multicolumn{5}{|c|}{ Final water $($ cells $/ \mathrm{ml})$} \\
\hline Average & 1433 & 1389 & 9 & 35 \\
\hline Max & 11,230 & 11,200 & 165 & 291 \\
\hline Min & 45 & 0 & 0 & 0 \\
\hline \multicolumn{5}{|c|}{ Tap water $(\mathrm{cells} / \mathrm{ml})$} \\
\hline Average & 1199 & 1162 & 7 & 30 \\
\hline Max & 7178 & 7165 & 173 & 290 \\
\hline Min & 81 & 0 & 0 & 0 \\
\hline
\end{tabular}

combined with sand filtration for elimination of cyanobacterial cells. Nevertheless, highest cell counts during the 3 years monitoring program were more than $2 \times 10^{6}$ cells $/ \mathrm{ml}$ in raw water. Even a reduction by $99.9 \%$ result in $>2000$ cells $/ \mathrm{ml}$ in final water. In fact, even cell densities of $>3000$ cells $/ \mathrm{ml}$ were found seven times in final water during the 46-week period presented above.

\subsection{Reduction of cyanobacterial toxins}

Two spot checks were taken at time points with high cell numbers of $M$. aeruginosa and A. circinalis to investigate the toxin concentrations during the treatment train (Table 4). As shown in Table 4, the excellent efficiency for removing cyanobacterial cells from the raw water $(>99 \%)$ did not automatically lead to an acceptable elimination of the produced toxins. MC elimination varied between the two spot checks. However, these differences were minor, if the standard deviations were taken into account. The standard deviations were the result of a triple determination of the MC concentrations by HPLC-DAD, ELISA and PPA. However, except for the MC detection after sand filtration (ASF) on 01/08/2001, the results of these three detection methods were in the same range. Nevertheless, on average these two spot checks demonstrated elimination rates of below $40 \%$ for flocculation and below $60 \%$ for combined flocculation and filtration. The proportion of extra cellular (free) toxin increased from $17.5 \%$ in raw to $97.9 \%$ after flocculation and filtration. The high concentration of free toxin in raw water $02 / 08 / 2001$ could be explained by a collapsing $M$. aeruginosa bloom at this time point and therefore an increasing lysis of cyanobacterial cells, which may also explain the lower elimination of MCs by flocculation. In addition, freeze-dried material of the surface bloom from 01/08/2001 was analysed and found to contain $67 \mu \mathrm{g} \mathrm{MC/g} \mathrm{DW,} \mathrm{whereas} \mathrm{in} \mathrm{sludge} \mathrm{after} \mathrm{flocculation} \mathrm{only}$ $5 \mu \mathrm{g} \mathrm{MC} / \mathrm{g}$ DW were detectable, obviously a result of cell lysis during and after flocculation or from degradation processes. The detected concentrations of PSPs were below $100 \mathrm{ng} / \mathrm{l}$ in the investigated samples. The extraction procedure of the samples was optimised for MCs and not for PSPs, so only a small part of the PSPs could be detected. Parallel investigations of Queensland Health Scientific Services (QHSS) with optimised sample preparation for PSPs demonstrated concentrations of 15 and $17 \mu \mathrm{g} / \mathrm{l}$ in raw water at $01 / 08$ and 22/08/01, respectively (Fig. 1c). Nevertheless, the results pointed to insufficient elimination of PSPs of $\sim 40 \%$ after flocculation and $\sim 60 \%$ after flocculation and filtration.

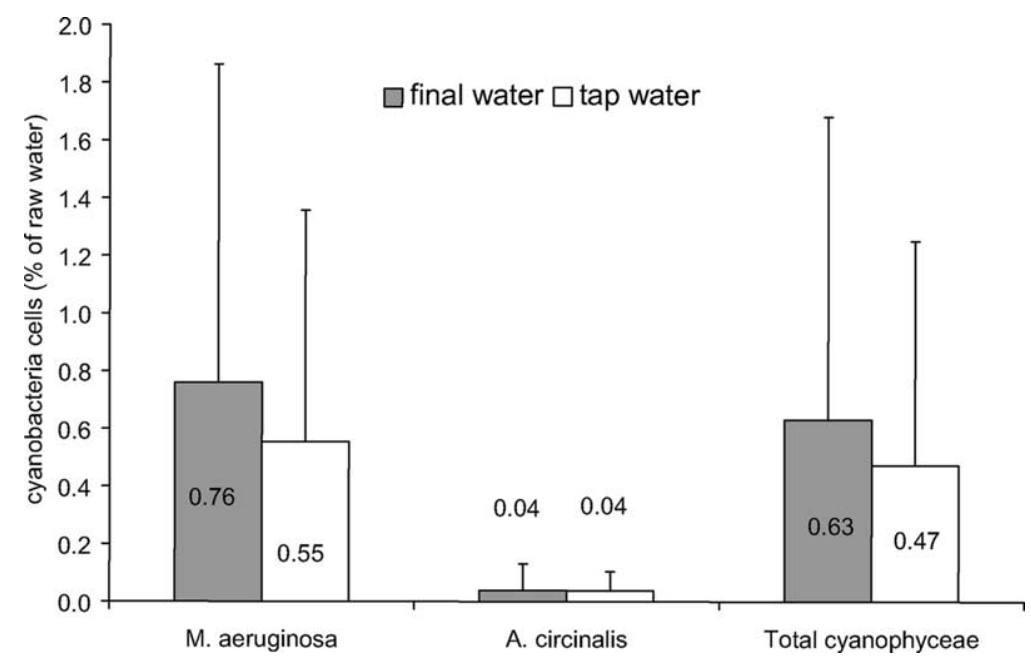

Fig. 2. Cell residual in final and tap water as \% cells compared to cells in raw water at WTP $1(n=35-47)$. 
Table 4

Removal of cyanobacterial cells and reduction of toxin concentration during the drinking water treatment at WTP 1

\begin{tabular}{|c|c|c|c|c|c|c|c|}
\hline & & \multicolumn{3}{|l|}{ 01/08/2001 } & \multicolumn{3}{|l|}{$22 / 08 / 2001$} \\
\hline & & RW & $\mathrm{AF}$ & ASF & RW & $\mathrm{AF}$ & $\mathrm{ASF}$ \\
\hline & M. aeruginosa & 54,000 & 570 & 165 & 25,500 & NI & 220 \\
\hline & A. circinalis & 151,000 & 2300 & 2 & 55,900 & NI & 80 \\
\hline \multirow[t]{2}{*}{$\%$ Removal } & M. aeruginosa & - & 98.9 & 99.7 & - & - & 99.1 \\
\hline & A. circinalis & - & 98.5 & 99.9 & - & - & 99.9 \\
\hline \multirow[t]{2}{*}{ Toxin (ng/l) } & MCs & $820 \pm 160$ & $470 \pm 150$ & $310 \pm 350$ & $740 \pm 170$ & $640 \pm 230$ & $570 \pm 70$ \\
\hline & PSPs & 68 & 40 & 33 & 79 & 45 & 30 \\
\hline \multirow[t]{2}{*}{$\%$ Removal } & $\mathrm{MCs}$ & - & 42.5 & 61.9 & - & 13.1 & 22.6 \\
\hline & PSPs & - & 41.0 & 51.0 & - & 42.9 & 62 \\
\hline$\%$ Free toxin & $\mathrm{MCs}$ & 17.5 & 97.9 & 97.9 & 43.5 & 99.5 & 100 \\
\hline
\end{tabular}

AF: after flocculation, ASF: after sand filtration and flocculation, NI: not investigated, RW: raw water.

\subsection{WTP 2}

In the drinking water dam of WTP 2, C. raciborskii is the dominant species (Table 1). The efficiency to eliminate CYN from raw water is shown in Fig. 3. The concentration of $\mathrm{CYN}$ in raw water of $1.17 \mu \mathrm{g} / \mathrm{l}$ was reduced by flocculation to $0.63 \mu \mathrm{g} / \mathrm{l}(46 \%)$, and by filtration and chlorination to below the detection limit of $0.2 \mu \mathrm{g} / \mathrm{l}$ (100\%). In raw water $20.5 \%$ of CYN was dissolved, whereas $38.1 \%$ of the toxins were released from cells after flocculation. No MCs were detectable in these samples.

\section{Discussion}

Both predominant species occurring in the raw water of the WTP 1 are known toxin-producers showing highly elevated cell numbers perennially. While M. aeruginosa reached extremely high cell densities, toxin concentrations

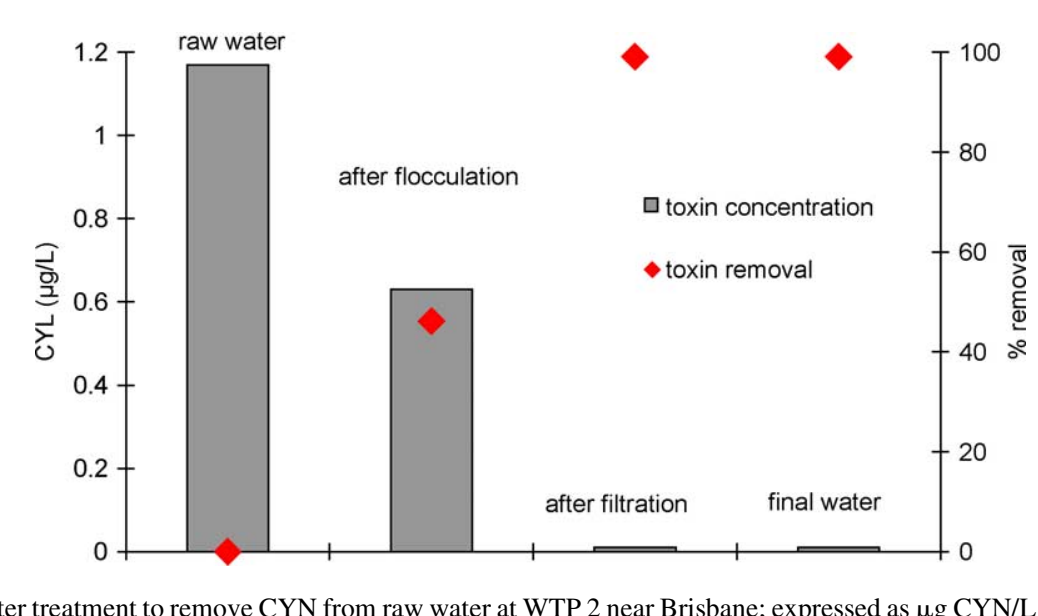

Fig. 3. Efficiency of water treatment to remove CYN from raw water at WTP 2 near Brisbane; expressed as $\mu \mathrm{g}$ CYN/L (left axis) and \% removal (right axis).

never exceeded $8.0 \mu \mathrm{g} / \mathrm{l}$. Interestingly, the highest toxin levels were not found to coincide with the highest cell counts. In contrast, toxin levels increased at the beginning of the exponential growth phase, when $M$. aeruginosa appeared to compete with A. circinalis for the dominant position in the lake. After suppression of the competitor, MCs concentrations decreased to a non-detectable level (Fig. 1a-c). This is in contrast to the situation with A. circinalis and the levels of PSP, where a strong correlation between PSP concentrations and cell densities was found. The competition between these two cyanobacterial species becomes obvious in Fig. 1a-c. This discussion assumes, that $A$. circinalis did not produce any MCs. Although 2 out of 24 French strains of $A$. circinalis were reported to synthesize MCs (Vezie et al., 1998), no MCs production was found in Australian strains (Velzeboer et al., 2000). In the case of $M$. aeruginosa there are two possible explanations for this phenomenon of varying MCconcentrations: (1) the species can switch toxin 
production on and off, depending on the situation given in the environment; (2) there are two or more strains of $M$. aeruginosa, 'toxin producers' and 'non-producers' present at the same time. Genetic heterogeneity is possible in cases of monospecific blooms as several studies have described toxic and non-toxic laboratory cultures of the same species, even when isolated from the same population (Carmichael and Gorham, 1977; Kangatharalingam and Priscu, 1993; Henriksen et al., 1997). In another study the correlation factor between MC-LR and densities of M. aeruginosa only explained $38-48 \%$ of the variation in concentrations of MC-LR, whereas $70 \%$ of the samples that contained no detectable MC-LR contained $M$. aeruginosa ( $>1000$ cells/ml; Kotak et al., 1995). Such a competitive mechanism is probable especially as possible $\mathrm{ABC}$ transport genes have been shown to co-locate to genes coding for toxin synthesis enzymes (Tillet et al., 2000). Investigations of effects of cyanobacterial secondary metabolites to other cyanobacteria (Schlegel et al., 1998), eukaryotic algae (Zakaria, 2002), diatoms (Keating, 1978) and higher plants (MacKintosh et al., 1990) have shown allelopathic effects. However, while such transporters and/or receptors for these secondary metabolites are unknown, the question concerning this phenomenon cannot be answered yet satisfactorily. Park et al. (1998) reported high concentrations of MC during the exponential growth phase of the bloom and release of $\mathrm{MC}$ from cells during bloom senescence and decomposition. In contrast, $A$. circinalis produced toxin in correlation to cell density. The PSP concentrations were higher than the levels for MCs synthesized by Microcystis. Oh et al. (2001) found correlations of MC concentrations versus chlorophyll-a and cell density, respectively, in a Korean lake with dominant Microcystis and Anabaena. In contrast, but also in agreement with the present data, no correlation was observed with Microcystis or Anabaena densities. Cronberg et al. (1999) even reported the highest toxin production at very low cyanobacterial biomass. The fact, that cyanobacteria produce different amounts of toxins under different conditions and in different seasons are mentioned in the literature: indeed, Henriksen and Moestrup (1997) found a ninefold increase of MCs/g DW of M. aeruginosa during 2 months and a remarkable doubling of the MC concentration of $M$. viridis collected within a 2-day interval. Other studies have explained the variations of toxin contents with solar radiation, water temperature, $\mathrm{pH}$, primary production and oxygen saturation in the water (Wicks and Thiel, 1990) or with differences in the toxin production in the different growth phases and with seasonal changes in the predominant toxic or non-toxic species of Microcystis (Park et al., 1998). Toxic and non-toxic strains within one field sample are well documented. Twelve different strains of Microcystis were isolated from one Microcystis bloom by Henning et al. (1997), eight of which were toxic, four of them not. Briand et al. (2002) proposed in a case of a perennial population of $P$. agardhii in France, that non-toxic strains grow in winter, whereas toxic ones grow in spring and autumn. As another source for MCs, picocyanobacteria with a typical diameter of $0.2-2 \mu \mathrm{m}$ appear in all environments including lakes, dams and drinking water reservoirs (Komárek, 1996) and exist in mixed communities with other planktic scum-forming cyanobacteria (Wilde and Cody, 1998). These small cyanobacteria are difficult to see and to analyse, but are also able to produce MC or MC-like compounds (Bláha and Mařsálek, 1999) and may influence the concentration of MCs in water samples. An additional reason for the poor correlation between cell densities and measured toxins could be the kinetics of natural degradation of these two toxin groups. The pattern of PSP concentration shown in Fig. 1a and $\mathrm{b}$ could be interpreted as slow degradation. Degradation of PSPs seems to be a more chemically mediated process, and these toxins appear to be able to persist in the water body for more than 3 months (Jones and Negri, 1997). In contrast, the most important degradation pathways for MCs are enzymatic mineralisation by bacterial degradation and degradation photosensitised by humic substances (Welker et al., 2001). Because of the initial lag-phase in microbial activity and only low rates of photochemical degradation resulting from low radiation energy reaching and penetrating the surface, MCs can persist for days or even weeks. However, the presented data do not give any evidence that free MCs persist for longer periods in the investigated reservoirs.

The water suppliers must eliminate potential harmful substances from the raw water in order to provide healthy drinking water for the population. MCs and PSPs elimination of $20-60 \%$ and $10-60 \%$, respectively, after flocculation/filtration as observed in this study was comparable to data in the literature (Hitzfeld et al., 2000). Cell-bound MCs decreased while extracellular toxin concentrations remained constant after flocculation and filtration. These findings are in accordance with results presented elsewhere: in these investigations, flocculation was effective in removing cells, but not in eliminating free MCs (James and Fawell, 1991; Rositano and Nicholson, 1994) and the concentration of other extra-cellular secondary metabolites remained constant after flocculation with aluminium sulphate (Velzeboer et al., 1995; Chow et al., 1999) or ferric chloride (Chow et al., 1998). However, the concentrations of flocculants used during these experiments were clearly lower (up to $4.8 \mathrm{mg} / \mathrm{l}$ ) compared to the situation in the water treatment plant investigated in this study $(120 \mathrm{mg} / \mathrm{l})$. Studies on the stability of cells during flocculation tend to be contradictory. No additional release could be observed in several studies (Velzeboer et al., 1995; Chow et al., 1999). However, Drikas et al. (2001) tested the efficiency of a treatment train with flocculation $(65 \mathrm{mg} / \mathrm{l})$ and sand filtration to remove $M$. aeruginosa cells from raw water and found that these processes cause little damage to cells and release a minimal amount of toxin. In another study, flocculation and filtration resulted in an increase of extracellular toxin after experiments with $M$. aeruginosa and Planktothrix rubescens (Pietsch et al., 2002). The researchers suggested turbulences 
in pipes and pressure gradients in the filter as reasons for the elevated extracellular toxin concentration. Experiments with cyanobacterial extracts resulted in toxin reduction by $11-32 \%$ after Al-flocculation (36-79 mg/l), sand filtration and chlorination (Himberg et al., 1989). Additional PAC (5 mg/l) improved the removal of MCs only to $13-34 \%$. One possible explanation for the increase in extracellular toxin could be the degradation of cellular material occurring in the sunken sludge. This post-flocculation sludge and the cells remaining in the sand filter could explain the higher extracellular toxin concentrations after treatment in the daily routine of a water treatment plant. Thus, thorough removal of the sludge and timely backwashing of the filters are essential. In addition, the DOC content of the raw water is crucial for the success of the flocculation/filtration process (Clasen et al., 2000). Thus, for the removal of cyanobacterial cells the percentage of removal cannot be estimated by laboratory investigations, because the raw water conditions in the individual water treatment plants are different. For elimination of PSPs during the treatment process, activated carbon in granular (GAC) or powdered form (PAC) was shown to be very effective (Newcombe et al., 2001). Thus, in this water treatment plant the treatment with PAC is recommended when A. circinalis reaches or has reached high densities in order to adsorb the dissolved PSPs. In contrast to GAC, which is used as a filtration step and as a growing medium for biofilm building bacteria, PAC is added freshly to the water after the flocculation step and thus has the full adsorptive capacity of activated carbon. Although MCs could not be detected in tap water during a 1 year investigation, the high cell numbers of $M$. aeruginosa in tap water (up to $10^{4}$ cells $/ \mathrm{ml}$ ) and detection of PSPs in final water give enough reason to improve the efficacy of the water treatment train. As a result of a the detection limits of 0.5 and $0.2 \mu \mathrm{g} / \mathrm{l}$ for PSPs (HPLC-FD) and MCs (HPLCDAD with preconcentration), respectively, a contamination with lower concentrations of toxins cannot be excluded. The spot check investigations of final water with ELISA, PPA and HPLC provided concentrations near this detection limit. The efficacy of chlorine $(0.5 \mathrm{mg} / \mathrm{l})$ to destroy MCs and PSPs is doubtful (Hitzfeld et al., 2000). Furthermore, intact cells could be destroyed by chlorine during storage and the intracellular toxin released into tap water. Mechanical pressure due to pumping of the water is also a potential cause for lysis of cyanobacterial cells during the passage from water treatment plants to households. The results have also shown that even if cell density is low in raw water, high cell numbers can still occur in final water tanks. This phenomenon could be explained by persisting high cell numbers in the final water reservoirs due to preceding periods with high cell densities in raw water (Lepistö et al., 1994) or by high cell numbers in the sand filter which may be washed out with the next water charge.

As expected, MCs could not be detected in WTP 2, because no MC-producing species grew at this time point in the water body. Although only $1.1 \mu \mathrm{g}$ CYN/l was found in raw water, a weekly monitoring of the raw water source is recommended, as cell densities at the time point of the spotcheck were low compared to reported bloom events of C. raciborskii in this reservoir. C. raciborskii is, similar to $P$. rubescens in another climatic region, difficult to recognize from the surface because the population is distributed through the water column. To avoid other phytoplankton intake, many water treatment plants have set their water intake at a deeper layer. The well-equipped water treatment system at this dam eliminated more than $99 \%$ of the toxin during flocculation, sand filtration and chlorination. PAC was not added on the sample day. However, the treatment efficiency could be completely different with a higher cell number over a longer period.

Because of the low toxicity of the M. aeruginosa strains during the investigation, toxin concentrations exceeding the guideline value of $1.3 \mu \mathrm{g} / \mathrm{l}$ (NHMRZ/ARMCANZ, 2001) in tap water were not detected. The lack of correlation between cell densities and toxin concentration, especially for $M$. aeruginosa and MCs, is an important fact for water treatment plants. One-third of the raw water samples were contaminated with significant concentrations of cyanobacterial toxins. The risk of a break-through of toxin concentrations exceeding the Australian guidelines is possible. Thus, variations in cyanobacterial densities and toxin production (amount and kind of toxin) during the year show, that monitoring of phytoplankton and measuring of toxin concentrations during the treatment steps is crucial to allow production of safe drinking water.

\section{Acknowledgements}

We would like to thank Queensland Health for providing the raw data for the long term study at WTP 1 and the participating water treatment plants for supporting the project. This study was supported by a fellowship to S.J.H. from the German Federal Environment Foundation (Osnabrueck, Germany) and the Universitätsgesellschaft Konstanz e.V. for the travel grant for S.J.H.

\section{References}

Beltran, E.C., Neilan, B.A., 2000. Geographical segregation of the neurotoxin-producing cyanobacterium Anabaena circinalis. Applied and Environmental Microbiology 66(10), 4468-4474.

Bláha, L., Mařsálek, B., 1999. Microcystin production and toxicity of picocyanobacteria as a risk factor for drinking water treatment plants. Archiv für Hydrobiologie Supplementband 127(0), 95-108.

Briand, J.F., Robillot, C., Quiblier-Lloberas, C., Bernard, C., 2002. A perennial bloom of Planktothrix agardhii (Cyanobacteria) in a shallow eutrophic French lake: limnological and microcystin production studies. Archiv für Hydrobiologie 153(4), 605-622. 
Byth, S., 1980. Palm island mystery disease. Medical Journal of Australia 2, 40-42.

Carmichael, W.W., Gorham, P.R., 1977. Factors influencing the toxicity and animal susceptibility of Anabaena flos-aquae (Cyanophyta) blooms. Journal of Phycology 13, 97-101.

Chong, M.W., Wong, B.S., Lam, P.K., Shaw, G.R., Seawright, A.A., 2002. Toxicity and uptake mechanism of cylindrospermopsin and lophyrotomin in primary rat hepatocytes. Toxicon 40(2), 205-211.

Chow, C.W.K., House, J., Velzeboer, R.M.A., Drikas, M., Burch, M.D., Steffensen, D.A., 1998. The effect of ferric chloride flocculation on cyanobacterial cells. Water Research 32(3), 808-814.

Chow, C.W.K., Drikas, M., House, J., Burch, M.D., Velzeboer, R.M.A., 1999. The impact of conventional water treatment processes on cells of the cyanobacterium Microcystis aeruginosa. Water Research 33(15), 3253-3262.

Clasen, J., Mischke, U., Drikas, M., Chow, C., 2000. An improved method for detecting electrophoretic mobility of algae during the destabilisation process of flocculation: flocculant demand of different species and the impact of DOC. Aqua 49(2), 89-101.

Cronberg, G., Annadotter, H., Lawton, L., 1999. The occurrence of toxic blue-green algae in Lake Ringsjön, southern Sweden, despite nutrient reduction and fish biomanipulation. Hydrobiologia 404, 123-129.

Drikas, M., Chow, C.W.K., House, J., Burch, M.D., 2001. Using coagulation, flocculation and settling to remove toxic cyanobacteria. American Water Works Association Journal 93(2), $100-111$.

Eaglesham, G.K., Norris, R.L., Shaw, G.R., Smith, M.J., Chiswell, R.K., Davis, B.C., Neville, G.R., Seawright, A.A., Moore, M.R., 1999. Use of HPLC-MS/MS to monitor cylindrospermopsin, a blue-green algal toxin, for public health purposes. Environmental Toxicology 14(1), 151-154.

Falconer, I.R., Beresford, A.M., Runnegar, M.T.C., 1983. Evidence of liver damage by toxin from a bloom of the blue-green alga Microcystis aeruginosa. Medical Journal of Australia 1, 511-514.

Fawell, J., James, C., James, H., 1994. Toxins from blue-green algae: toxicological assessment of microcystin-LR and a Method for its determination in water, Foundation for Water Research, Marlow.

Fischer, W.J., Garthwaite, I., Miles, C.O., Ross, K.M., Aggen, J.B., Chamberlin, A.R., Towers, N.R., Dietrich, D.R., 2001. Congener-independent immunoassay for microcystins and nodularins. Environmental Science and Technology 35(24), 4849-4856.

Fitzgerald, D.J., Cunliffe, D., Burch, M., 1999. Development of health alerts for cyanobacteria and related toxins in drinking water in South Australia. Environmental Toxicology 14, 203-209.

Francis, G., 1878. Poisonous Australian lake. Nature 18, 11-12.

Froscio, S.M., Humpage, A.R., Burcham, P.C., Falconer, I.R., 2001. Cell-free protein synthesis inhibition assay for the cyanobacterial toxin cylindrospermopsin. Environmental Toxicology 16(5), $408-412$.

Fujiki, H., Suganuma, M., 1999. Unique features of the okadaic acid activity class of tumor promoters. Journal of Cancer Research and Clinical Oncology 125, 150-155.

Hawkins, P.R., Runnegar, M.T., Jackson, A.R., Falconer, I.R., 1985. Severe hepatotoxicity caused by the tropical cyanobacter- ium (blue-green alga) Cylindrospermopsis raciborskii (Woloszynska) Seenaya and Subba Raju isolated from a domestic water supply reservoir. Applied and Environmental Microbiology 50(5), 1292-1295.

Henning, K., Woitke, P., Rohrlack, T., 1997. Pigment- und Toxinmuster von isolierten Microcystis-Stämmen. WaBoLu Hefte. Institut für Wasser-, Boden- und Lufthygiene 4 , 149-150.

Henriksen, P., Moestrup, O., 1997. Seasonal variations in microcystin contents of Danish cyanobacteria. Natural Toxins 5(3), 99-106.

Henriksen, P., Carmichael, W.W., An, J.S., Moestrup, O., 1997. Detection of an anatoxin-a(s)-like anticholinesterase in natural blooms and cultures of Cyanobacteria/blue-green algae from Danish lakes and in the stomach contents of poisoned birds. Toxicon 35(6), 901-913.

Herath, G., 1995. The algal bloom problem in Australian waterways: an economic appraisal. Review of Marketing and Agricultural Economics 63, 77-86.

Heresztyn, T., Nicholson, B.C., 2001. Determination of cyanobacterial hepatotoxins directly in water using a protein phosphatase inhibition assay. Water Research 35(13), 3049-3056.

Himberg, K., Keijola, A.-M., Hiisvirta, L., Pyysalo, H., Sivonen, K., 1989. The effect of water treatment processes on the removal of hepatotoxins from Microcystis and Oscillatoria cyanobacteria: a laboratory study. Water Research 23, 979-984.

Hitzfeld, B.C., Hoeger, S.J., Dietrich, D.R., 2000. Cyanobacterial toxins: removal during drinking water treatment, and human risk assessment. Environmental Health Perspectives 108(Suppl. 1), $113-122$

Hoeger, S.J., Dietrich, D.R., Hitzfeld, B.C., 2002. Effect of ozonation on the removal of cyanobacterial toxins during drinking water treatment. Environmental Health Perspectives 110(11), 1127-1132.

Humpage, A.R., Fenech, M., Thomas, P., Falconer, I.R., 2000. Micronucleus induction and chromosome loss in transformed human white cells indicate clastogenic and aneugenic action of the cyanobacterial toxin, cylindrospermopsin. Mutation Research/DNA Repair 472(1/2), 155-161.

James, H., Fawell, J., 1991. Detection and removal of cyanobacterial toxins from freshwaters. FR 0211, Foundation for Water Research, Marlow.

Jones, G., Negri, A., 1997. Persistence and degradation of cyanobacterial paralytic shellfish poisons (PSPs) in freshwaters. Water Research 31, 525-533.

Kangatharalingam, N., Priscu, J.C., 1993. Isolation and verification of anatoxin-a producing clones of Anabaena flos-aquae (Lyngb.) de Breb. from a eutrophic lake. Fems 12(2), 127-130.

Keating, K.I., 1978. Blue-green algal inhibition of diatom growth: transition from mesotrophic to eutrophic lake. Science 199 971-973.

Komárek, J., 1996. Towards a combined approach for the taxonomy and species delimitation of picoplanktic cyanoprokaryotes. Archiv für Hydrobiologie Supplementband 117(0), 377-401.

Kotak, B.G., Lam, A.K.-Y., Prepas, E.E., Kenefick, S.L., Hrudey, S.E., 1995. Variability of the hepatotoxin, microcystin-LR, in hypereutrophic drinking water lakes. Journal of Phycology 31, $248-263$

Lawrence, J.F., Menard, C., Cleroux, C., 1995. Evaluation of prechromatographic oxidation for liquid chromatographic 
determination of paralytic shellfish poisons in shellfish. Journal of AOAC International 78(2), 514-520.

Lawton, L.A., Edwards, C., Codd, G.A., 1994. Extraction and highperformance liquid-chromatographic method for the determination of microcystins in raw and treated waters. Analyst 119(7), 1525-1530.

Lepistö, L., Lahti, K., Niemi, J., 1994. Removal of cyanobacteria and other phytoplankton in four Finnish waterworks. Algological Studies 75, 167-181.

MacKintosh, C., Beattie, K.A., Klumpp, S., Cohen, P., Codd, G.A., 1990. Cyanobacterial microcystin-LR is a potent and specific inhibitor of protein phosphatases 1 and $2 \mathrm{~A}$ from both mammals and higher plants. FEBS Letters 264(2), 187-192.

Newcombe, G., Cook, D., Morrison, J., Brooke, S., 2001. Water treatment options for saxitoxins: ozonation or activated carbon adsorption, Fifth International Conference on Toxic Cyanobacteria, Noosa, Australia,.

NHMRZ/ARMCANZ, 2001. Australian drinking water guidelines, micro-organism 3: toxic algae, Fact Sheets No. 17a-17d, National Health and Medical Research Council, Agriculture and Resource Management Council of Australia and New Zealand, Canberra.

Oh, H.M., Lee, S.J., Kim, J.H., Kim, H.S., Yoon, B.D., 2001. Seasonal variation and indirect monitoring of microcystin concentrations in Daechung reservoir, Korea. Applied and Environmental Microbiology 67(4), 1484-1489.

Park, H.-D., Iwami, C., Watanabe, M.F., Harada, K.-I., Okino, T., Hayashi, H., 1998. Temporal variabilities of the concentrations of intra- and extracellular microcystin and toxic Microcystis species in a hypertrophic lake, Lake Suwa, Japan (1991-1994). Environmental Toxicology and Water Quality 13(1), 61-72.

Pietsch, J., Bornmann, K., Schmidt, W., 2002. Relevance of intraand extracellular cyanotoxins for drinking water treatment. Acta Hydrochimica et Hydrobiologica 30(1), 7-15.

Rapala, J., Sivonen, K., 1998. Assessment of environmental conditions that favor hepatotoxic and neurotoxic Anabaena spp. strains cultured under light limitation at different temperatures. Microbial Ecology 36(2), 181-192.

Rositano, J., Nicholson, B., 1994. Water treatment techniques for the removal of cyanobacterial toxins from water, 2/94, Australian Centre for Water Quality.

Runnegar, M.T., Jackson, A.R., Falconer, I.R., 1988. Toxicity of the cyanobacterium Nodularia spumigena Mertens. Toxicon 26(2), $143-151$.

Runnegar, M., Shou-Ming, K., Ya-Zhen, Z., Shelly, C., 1995. Inhibition of reduced glutathione synthesis by cyanobacterial alkaloid cylindrospermopsin in cultured rat hepatocytes. Biochemical Pharmacology 49, 219-255.

Schlegel, I., Doan, N.T., de Chazal, N., Smith, G.D., 1998. Antibiotic activity of new cyanobacterial isolates from Australia and Asia against green algae and cyanobacteria. Journal of Applied Phycology 10(5), 471-479.

Tillet, D., Dittmann, E., Erhard, M., von Döhren, H., Börner, T., Neilan, B., 2000. Structural organization of microcystin biosynthesis in Microcystis aeruginosa PCC 7806: an integrated peptide-polyketide synthetase system. Chemistry and Biology 7 , 753-764.

Velzeboer, R., Drikas, M., Donati, C., Burch, M., Steffensen, D., 1995. Release of geosmin by Anabaena circinalis following treatment with aluminium sulphate. Water Science and Technology 31(11), 187-194.

Velzeboer, R.M.A., Baker, P.D., Rositano, J., Heresztyn, T., Codd, G.A., Raggett, S.L., 2000. Geographical patterns of occurrence and composition of saxitoxins in the cyanobacterial genus Anabaena (Nostocales, Cyanophyta) in Australia. Phycologia 39(5), 395-407.

Vezie, C., Brient, L., Sivonen, K., Bertru, G., Lefeuvre, J., Salkinoja-Salonen, M., 1998. Variation of microcystin content of cyanobacterial blooms and isolated strains in lake GrandLieu (France). Microbial Ecology 35(2), 126-135.

Vlaski, A., van Breemen, A., Alaerts, G., 1996. Optimisation of coagulation conditions for the removal if cyanobacteria by dissolved air flotation or sedimentation. Journal Water SRTAqua 45, 253-261.

Welker, M., Steinberg, C., Jones, G., 2001. Release and persistence of microcystins in natural waters, In: Chorus, I. (Ed.), Cyanotoxins-Occurrence, Effects, Controlling Factors. Springer, Berlin, pp. 83-110.

WHO, 1998. Cyanobacterial toxins: microcystin-LR, Guidelines for Drinking-Water Quality, World Health Organization, Geneva, Addendum to volume, pp. 95-110.

Wicks, R.J., Thiel, P.G., 1990. Environmental factors affecting the production of peptide toxins in floating scums of the cyanobacterium Microcystis aeruginosa in a hypertrophic African reservoir. Environmental Science and Technology 24(9), 1413-1418.

Wilde, E.W., Cody, W.R., 1998. Picoplankton counts greatly alter phytoplankton quantitative analyses results. Journal of Freshwater Ecology 13(1), 79-85.

Zakaria, M., 2002. Allelopathic activity of Spirogyra sp.: stimulation bloom formation and toxin production by Oscillatoria agardhii in some irrigation canals, Egypt. Journal of Plankton Research 24(2), 137-141. 